\title{
Innate Host Defense against Klebsiella pneumoniae and the Outlook for Development of Immunotherapies
}

\author{
Clement Opoku-Temeng Natalia Malachowa Scott D. Kobayashi \\ Frank R. DeLeo \\ Laboratory of Bacteriology, Rocky Mountain Laboratories, National Institute of Allergy and Infectious Diseases, \\ National Institutes of Health, Hamilton, MT, USA
}

\section{Keywords}

Antibiotic resistance $\cdot$ Phagocytosis · Neutrophil · Capsule polysaccharide $\cdot$ Vaccine

\section{Abstract}

Klebsiella pneumoniae (K. pneumoniae) is a Gram-negative commensal bacterium and opportunistic pathogen. In healthy individuals, the innate immune system is adept at protecting against K. pneumoniae infection. Notably, the serum complement system and phagocytic leukocytes (e.g., neutrophils) are highly effective at eliminating K. pneumoniae and thereby preventing severe disease. On the other hand, the microbe is a major cause of healthcare-associated infections, especially in individuals with underlying susceptibility factors, such as pre-existing severe illness or immune suppression. The burden of K. pneumoniae infections in hospitals is compounded by antibiotic resistance. Treatment of these infections is often difficult largely because the microbes are usually resistant to multiple antibiotics (multidrug resistant [MDR]). There are a limited number of treatment options for these infections and new therapies, and preventative measures are needed. Here, we review host de-

karger@karger.com www.karger.com/jin

Karger!"

BOPEN ACCESS
Published by S. Karger AG, Basel

This is an Open Access article licensed under the Creative Common Attribution-NonCommercial-4.0 International License (CC BY-NC) (http://www.karger.com/Services/OpenAccessLicense), applicable to the online version of the article only. Usage and distribution for commercial purposes requires written permission. fense against $K$. pneumoniae and discuss recent therapeutic measures and vaccine approaches directed to treat and prevent severe disease caused by MDR K. pneumoniae.

(c) 2021 This is a work of the U.S. Government and is not subject to copyright protection in the United States. Foreign copyrights may apply. Published by S. Karger AG, Basel.

\section{Introduction}

Klebsiella pneumoniae (K. pneumoniae; historically known as Friedlander's bacillus) is an opportunistic human and animal pathogen and a leading cause of hospital-acquired infections worldwide. The Gram-negative bacterium is ubiquitous in the environment and found in water, soil, and on plants. Moreover, K. pneumoniae is a human commensal and asymptomatically colonizes mucosal surfaces of the gastrointestinal tract and to a lesser extent the upper respiratory tract [1]. K. pneumoniae infection occurs typically in healthcare settings and the corresponding etiologic pathotype is now commonly referred to as classical K. pneumoniae (cKp) [2, 3]. Based on a recent analysis of data from the SENTRY
Correspondence to:

Frank R. DeLeo, fdeleo@ niaid.nih.gov 
Antimicrobial Surveillance Program, which spans a 20year period (1997-2016), K. pneumoniae ranks third behind Staphylococcus aureus and Escherichia coli as a leading cause of bloodstream infections worldwide [4]. In addition to bloodstream infections, cKp commonly presents as urinary tract infection, surgical site infection, and pneumonia $[1,5]$. The risk factors for infection include use of indwelling medical devices (e.g., catheters and ventilators) and co-morbidities such as surgery, diabetes, and cancer [5]. In contrast to $\mathrm{cKp}$, some strains of $K$. pneumoniae cause community-acquired infections in otherwise healthy individuals, and the enhanced pathotype is termed hypervirulent $K$. pneumoniae (hvKp) $[3,6]$. HvKp was initially described in case reports from Taiwan, and the disease manifested as primary liver abscesses with dissemination $[7,8]$. Since the original reports in the 1980s, infections caused by hvKp are increasingly reported worldwide [3]. Several K. pneumoniae factors linked to enhanced virulence of hvKp strains reside on mobile genetic elements and contribute to increased capsule production/hypermucoviscosity and iron acquisition [9]. For example, the regulator of mucoid phenotype A ( $r m p A$ and $r m p A 2)$ and multiple iron acquisition systems such as iroBCDN and $i u c A B C D$ are encoded on a large virulence plasmid named pLVPK [10]. Although infections with hvKp are associated with liver abscesses in otherwise healthy individuals, the clinical spectrum of disease is diverse and the risk factors complex [11]. For example, diabetes is a common risk factor for disseminated hvKp infection [3], and hypervirulent strains have made inroads into healthcare settings $[12,13]$. Compared with multidrug-resistant (MDR) cKp strains, the epidemiologic lineage of hvKp is more limited and predominated by 3 clonal groups (CGs) - namely, CG23, CG65, and CG86 [14]. The diverse clinical spectrum of $K$. pneumoniae disease is confounded by the problem of expanding drug resistance in cKp and hvKp (Fig. 1).

Antimicrobial resistance is a global concern and is included as high priority in recent reports by the US Centers for Disease Control and Prevention, the World Health Organization, and the Public Health Agency of Canada [15]. Enterobacteriaceae such as K. pneumoniae and Escherichia coli are notorious for developing antimicrobial resistance. Cephalosporin and carbapenem antibiotics have historically been a mainstay therapy for treatment of severe infections caused by these pathogenic microbes [16]. However, in the late 1980s and 1990s, there was emergence of K. pneumoniae and E. coli strains that were resistant to cephalosporin, penicillin, and monobactam antibiotics due to the acquisition of extended-spectrum beta-lactamases (ESBLs) (Fig. 1). ESBLs are plasmid-encoded enzymes that hydrolyze betalactam antibiotics, and the plasmids frequently encode additional antimicrobial molecules that confer resistance to fluoroquinolones, cotrimoxazole, and aminoglycosides [17]. The ESBL-producing cKp strains became an increasing cause of hospital outbreaks and contributed to increased economic burden. Indeed, the SENTRY study indicates ESBL-producing cKp continue to increase in hospitals and the community [4]. Although carbapenem antibiotics are largely effective against ESBL-containing bacteria, use of these antibiotics increased and there was concomitant emergence of carbapenem-resistant $K$. pneumoniae strains [18]. These strains contain a novel class A $\beta$-lactamase termed $K$. pneumoniae carbapenemase, which confers resistance to virtually all $\beta$-lactam antibiotics. Multilocus sequence type 258 (ST258; assigned to CG258) K. pneumoniae are the most prominent $K$. pneumoniae carbapenemasecontaining organisms in US hospitals and many other regions worldwide $[19,20]$. Carbapenem resistance is also conferred by New Delhi metallo- $\beta$-lactamase 1 , and thus carbapenem-resistant strains are currently worldwide in distribution. In addition to CG258, there are a number of other important MDR K. pneumoniae lineages distributed globally [14]. The genomic population structure of these lineages has been reviewed recently by Wyres et al. [14]

MDR bacteria represent a substantial public health burden and have stretched the thinning antibacterial therapeutic pipeline [21]. Treatment options are often limited. For example, most ST258 isolates are resistant to virtually all $\beta$-lactam antibiotics and have decreased susceptibility to aminoglycosides, fluoroquinolones, and many other clinically relevant antibiotics [22]. Antibiotic susceptibility of carbapenem-resistant K. pneumoniae is often limited to colistin, tigecycline, and gentamicin, although the prevalence of strains resistant to these compounds has increased recently [23-28]. Resistance to colistin is notable because it can be transferred readily among Enterobacteriaceae by plasmid-encoded $m c r$ genes [29-31]. Treatment of carbapenem-resistant $K$. pneumoniae infections with $\beta$-lactamase inhibitor combinations such as ceftazidime/avibactam and meropenem/vaborbactam has been successful [32-34], but development of resistance is also a significant concern [35]. There is currently no licensed vaccine for prevention of infections caused by K. pneumoniae, and the recent emergence of carbapenem resistance in hyperviru- 


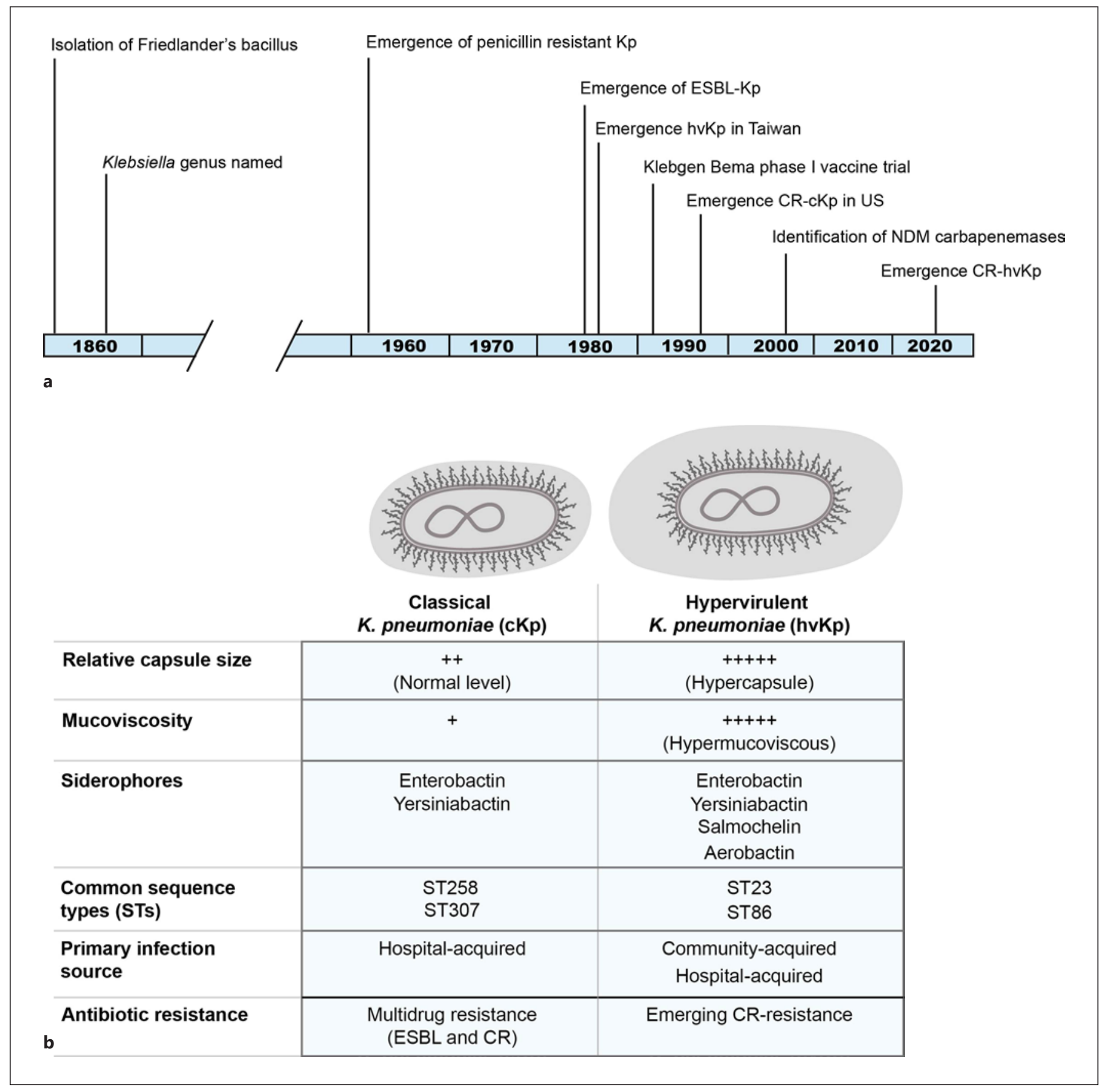

Fig. 1. cKp and hvKp. a Timeline of the emergence of multidrug resistance in K. pneumoniae. b Distinguishing features of cKp and hvKp strains. Kp, Klebsiella pneumoniae; $\mathrm{CKp}$, classical K. pneumoniae; hvKp, hypervirulent K. pneumoniae; ESBL, extended-spectrum beta-lactamase; NDM, New Delhi metallo- $\beta$-lactamase; Ent, enterobactin; Ybt, yersiniabactin.

lent strains in both community and healthcare settings underscores the need for development of alternative approaches for prevention and/or treatment of infections caused by these organisms [36-40]. Here, we provide a cursory overview of the host response to K. pneumoniae infection and discuss the potential for development of novel immunotherapies and vaccines. 


\section{Serum Complement and Complement Resistance}

The serum complement system facilitates microbial clearance by augmenting the function of phagocytic cells and/or causing direct lysis of bacteria via formation of the membrane attack complex. Accordingly, defects in the complement system afford K. pneumoniae survival in serum. For example, Bain et al. [41] showed that in vitro depletion of alternative pathway factors resulted in increased survival of $K$. pneumoniae in serum. Consistent with these findings, there was increased dissemination of $K$. pneumoniae from experimentally infected lungs to the spleen of mice genetically deficient in factor B or C3 [41]. Although the complement system is a formidable defense against invading microbes, pathogens such as $\mathrm{K}$. pneumoniae have evolved strategies to evade killing by serum complement. Notably, a thick capsule polysaccharide (CPS) layer coats the exterior of the bacterium and provides a physical barrier to host molecules present in serum [42]. The CPS consists of a polymer of sugar units known as $\mathrm{K}$ antigens and is synthesized by enzymes encoded in the cps locus - a set of largely conserved chromosomal genes. Variations in the polysaccharide constituents and structure which result from difference in $c p s$ loci yield different $\mathrm{K}$ antigens, which were classified traditionally by serotype $[43,44]$. More recent studies classify K. pneumoniae capsules based on the conserved $w z i$, $w z c$, and/or $w z y$ genes of the cps locus, or by whole genome data [45-49].

To evade killing by serum complement, the CPS masks subsurface structures that trigger complement activation, such as outer membrane protein $\mathrm{K} 36$ (OmpK36) [50, 51]. Hence, strains that produce high levels of CPS are typically resistant to serum bactericidal activity $[5,52]$. Consistent with these observations, acapsular mutant strains have higher levels of C3 deposition and are more susceptible to killing by serum complement than capsule-positive strains [53]. Indeed, when CPS synthesis was inhibited following treatment of encapsulated $K$. pneumoniae with bismuth dimercaprol, C3b deposition and anti-O1 LPS $m A b$ reactivity increased because subsurface structures were exposed [54]. Recently, Jensen et al. [55] showed that following treatment with serum, susceptible $K$. pneumoniae strains had significant loss of capsule structure and damage to the outer membrane compared with serum resistant strains.

LPS is also known for its ability to protect $K$. pneumoniae against complement-mediated killing [56]. This important bacterial surface structure comprises a lipid A moiety, an oligosaccharide core unit, and a hypervariable polymer of sugars known as the O-antigen. LPS is classified by the length of the $\mathrm{O}$-antigen as either smooth or rough. Strains expressing a smooth LPS phenotype (smooth LPS) have full-length (high molecular weight) O-antigens, whereas strains with a rough LPS phenotype (rough LPS) have truncated (low molecular weight) Oantigens or lack O-antigens. Generally, strains expressing smooth LPS are less susceptible to bactericidal activity of serum complement than their rough LPS-expressing counterparts [57]. Indeed, studies by Alberti et al. [50, 51] showed that K. pneumoniae strains expressing smooth LPS bound less C1q, and there was decreased activation of the classical pathway compared with strains with the rough LPS. Moreover, O-antigens of smooth LPS bind and sequester $\mathrm{C} 3 \mathrm{~b}$ more distant from the bacterial membrane compared with rough LPS, a phenomenon that hinders the formation of the membrane attack complex [56]. It is notable that rough LPS mutants are susceptible to complement-mediated killing in the presence or absence of CPS [56], an observation that brings into question the unique role of CPS in resistance to serum bactericidal activity.

Although LPS and CPS are considered the factors largely responsible for serum resistance, other K. pneumoniae components have been shown to protect against complement-mediated killing. For example, strains deficient in pal and $\ln p A$, genes that encode outer membrane proteins (Omps), are more susceptible to complementmediated killing than wild-type strains [58]. A recent genome-scale analysis of $\mathrm{K}$. pneumoniae identified $r f a H$ (an antiterminator), $l p p$, and $a r n D$ (an LPS modification gene) as genes that play a role in complement resistance [59]. Furthermore, Bachman et al. [60] demonstrated that a mutant K. pneumoniae lacking aroE (encoding shikimate dehydrogenase) is more susceptible to serum killing than a wild-type strain. Thus, multiple molecules contribute to the serum resistance phenotype of $K$. pneumoniae.

\section{Phagocytes and Host Defense against K. pneumoniae}

Encapsulated bacteria such as K. pneumoniae are often resistant to phagocytosis [61], a characteristic linked to virulence [62]. The resistance to phagocytosis can typically be overcome by host opsonins, most notably a specific antibody combined with a serum complement, and/ or via surface phagocytosis $[61,63-65]$. Importantly, antibody-mediated phagocytosis has been utilized successfully for vaccine approaches directed to protect against encapsulated bacteria, including K. pneumoniae [66, 67]. 
On the other hand, Wood and Smith first proposed that nonantibody-mediated phagocytosis by adherent leukocytes - so-called surface phagocytosis - is also an important component of the innate host defense against encapsulated bacteria [63]. These authors demonstrated that Friedlander's bacillus phagocytosed by this process is ultimately destroyed within the leukocyte [68]. Not all studies concur with these early findings, and varied results might be explained by different host cell types and experimental assay conditions, or are strain/isolate-specific. For example, a more recent study by Cano et al. [69] reported that an hvKp strain (ATCC strain 43816, a serotype K2 strain used widely for mouse infection studies) alters maturation of the macrophage phagosome, thereby promoting intracellular survival and triggering macrophage-programmed cell death. It is not clear whether this phenomenon is strain-specific, but many bacterial pathogens are known to survive within macrophages.

Studies with a rabbit infection model and anti-polymorphonuclear leukocyte antisera provided strong support to the idea that neutrophils are the primary cellular defense against $K$. pneumoniae [70]. These findings were verified in mouse infection models in which neutrophils were shown to be necessary for defense against hvKp strain 43816 [71-73]. It is also worth noting that mice deficient in neutrophil elastase or myeloperoxidase have enhanced susceptibility to $K$. pneumoniae infection and death $[74,75]$, results that underscore a prominent role for neutrophils in host defense against $K$. pneumoniae. In humans, neutropenia is a predisposing factor to bacteremia caused by Klebsiella spp. [76], and mortality rates are high for bloodstream infections caused by carbapenemresistant Enterobacteriaceae [77, 78].

Mononuclear phagocytes also have a prominent role in host defense against $K$. pneumoniae infection [72, 7987]. For example, Xiong et al. [72] demonstrated that CCR2+ inflammatory monocytes contribute to innate host defense against $K$. pneumoniae in the mouse lung. In subsequent studies, the authors showed cross talk between inflammatory monocytes and innate lymphocytes, which involve TNF and IL-17A, leads to enhanced clearance of ST258 from the lungs of infected mice [86]. Consistent with this finding, IL-17A-deficient mice are more susceptible to ST258 infection than wild-type mice [86]. Broug-Holub et al. [82] used mice depleted of alveolar macrophages to evaluate the importance of these host cells following challenge with the hvKp strain 43816. Infected mice lacking alveolar macrophages had significantly decreased survival that was accompanied by more bacteria in the lungs compared to control mice [82]. Al- though PMN recruitment was not affected, clearance of bacteria from the lungs was impaired [82]. These findings are consistent with a need for macrophage inflammatory protein-2 to promote clearance of the hvKP strain by PMNs, as shown by this group in a separate work [88]. More recently, Ivin et al. [87] reported that increased type I IFN signaling, as a result of a cross talk between alveolar macrophages and natural killer cells, is important for host clearance of strain 43816 in a mouse lung infection model. Notably, increased IFN- $\gamma$ production by natural killer cells enhances the antimicrobial activities of alveolar macrophages [87].

Bhan et al. [85] used a mouse pneumonia model to show that dendritic cells (DCs) contribute to host defense against $K$. pneumoniae lung infection. In these studies, DCs were recruited to the lungs of mice infected with hvKp (also strain 43816) in a toll-like receptor 9 (TLR9)dependent fashion, as wild-type mice had fewer bacteria in the lungs and better survival than mice deficient in TLR9 [85]. Although the study used a K. pneumoniae infection model, the findings with DCs and TLR9 are likely applicable to lung infections caused by Gram-negative bacteria in general.

Multiple factors can influence contributions of mononuclear phagocytes in the defense against $K$. pneumoniae. Yokota et al. [80] reported that host age has a major impact on the ability of alveolar macrophages to defend against $K$. pneumoniae lung infection in mice. These researchers found that the function of alveolar macrophages rather than a change in the number of these phagocytes in the lungs decreased with age [80]. Subinhibitory concentrations of antibiotics can also increase susceptibility to killing by host macrophages, a phenomenon linked to altered capsule thickness, surface hydrophobicity, and charge [89-91].

Although host phagocytes are essential for defense against K. pneumoniae, many K. pneumoniae clinical isolates and/or strains are resistant to phagocytosis. The $K$. pneumoniae CPS has long been known to be a major determinant of resistance to phagocytosis [53, 92, 93]. For example, Cortés et al. [53] found that unencapsulated mutant $K$. pneumoniae strains were ingested more readily by human alveolar macrophages than wild-type strains. More recently, Ernst et al. [94] identified a single nucleotide polymorphism in the $w z c$ capsule biosynthesis gene that yielded cells with hypercapsule production and resistance to phagocytosis by macrophages. Kobayashi et al. [95] found that there is limited neutrophil phagocytosis of ST258 clinical isolates, a phenotype conferred largely by the CPS. Subsequent work by Diago-Navarro et al. 
[96], Kobayashi et al. [97], and Motley et al. [98] demonstrated that phagocytosis and killing of ST258 are enhanced significantly by CPS-specific antibodies [96-98]. These results provide strong support to the idea that the CPS of ST258 can be used as vaccine antigen and/or target.

K. pneumoniae LPS also contributes to resistance to leukocyte phagocytosis. Deletion of $w z m$, the gene involved in LPS O-antigen transport, renders K. pneumoniae more susceptible to $\mathrm{PMN}$ phagocytosis than wild-type strains [99]. In some K. pneumoniae strains, the CPS hinders recognition of LPS by masking the $\mathrm{O}$-antigens and hence limiting phagocytosis. For example, CPS has been reported to attenuate TLR4 signaling in macrophages [100]. However, when the underlying LPS structures were exposed after CPS was disrupted, TLR4 signaling was activated in these host leukocytes [100].

Omps, including Pal, LppA, and OmpA, inhibit neutrophil phagocytosis, consistent with a similar role in serum resistance [58]. It is also noteworthy that $K$. pneumoniae can undergo genetic adaptation to circumvent innate immunity, a process not unlike some of those that result in antibiotic resistance. For example, Ahn and colleagues determined that an ST258 clinical isolate - named KP35 in their study - had acquired new gene orthologs and thereby became resistant to phagocytosis by neutrophils and monocytes [101]. The authors found that this mutant ST258 isolate caused recruitment of immunosuppressive monocytes in a murine lung infection model and in turn altered pro-inflammatory cytokine production and calcium-dependent signal transduction required for killing by phagocytes [101]. The mechanisms underlying this intriguing finding remain incompletely determined and merit further investigation.

\section{Adaptive Immune Responses to K. pneumoniae}

The activities of serum complement and phagocytic leukocytes are important for the innate immune response to K. pneumoniae. Information from the innate immune system is passed on to components of the adaptive immune system usually by antigen-presenting cells [102]. Unlike innate immunity, the adaptive immune response is relatively slow, more specific, and characterized by the generation of immunological memory against reinfection by the same pathogen. Generally, the adaptive immune response can be classified as either cell-mediated, which involves $\mathrm{T}$-cell activation, or a humoral response, which is mediated by B cells and antibodies [103]. Compared with work in the area of innate immunity, fewer studies have investigated cell-mediated immunity against $K$. pneumoniae, although progress has been made. For example, Lee et al. [104] found that T-helper (Th) type 1, Th2, and Th17 lymphocytes produced IFN- $\gamma$, IL-4, and IL-17 following vaccination of mice with $K$. pneumoniaederived extracellular vesicles. Notably, IL-17 and IFN- $\gamma$ are important for resolution of $K$. pneumoniae infections $[105,106]$.

Glycan antigens such as CPS and LPS are generally thought to be less immunogenic and known to induce humoral immune responses in a T-cell independent fashion $[107,108]$. This implies that they may not induce the formation of memory cells, and hence any reinfection may appear as a new infection. Nonetheless, several studies have shown that these antigens have the capacity to elicit a strong humoral immune response and the antibodies produced are protective against $K$. pneumoniae infection (discussed below). For this reason, CPS- and LPSbased immunotherapies are viewed as a potential treatment strategy in the wake of the current antibiotic crisis.

Inasmuch as $K$. pneumoniae is a human commensal microorganism, it is not surprising that naturally occurring Klebsiella-specific antibodies can be detected in normal human sera. Lepper et al. [109] reported the presence of both CPS-specific ( $\mathrm{K}$ antigen) and LPS-specific ( $\mathrm{O}$ antigen) antibodies in the normal human sera of healthy donors. The study also showed that the K-antigen-specific antibodies were vital for clearing K. pneumoniae systemic infection and also enhanced phagocytosis of encapsulated K. pneumoniae strains by PMNs [109]. More recent studies demonstrated that a serum-sensitive ST258 isolate survived significantly better in IgG-depleted serum, an observation consistent with the presence of naturally occurring antibodies in human serum [110].

\section{Virulence and Animal Infection Models}

K. pneumoniae virulence factors are well positioned to provide strong defense against components of the host immune system [5]. CPS is an important and abundant virulence factor of $K$. pneumoniae. For example, K1 and K2 capsule serotypes are primarily associated with hvKp that causes pyogenic liver abscesses [44]. In addition to the immune evasion attributes described above, CPS is important for colonization of the oropharynx and lower gastrointestinal tract [111]. Increased capsule production and hypermucoviscosity in hvKp strains are mediated by a regulator of mucoid phenotype ( $r m p A$ and $r m p A 2)$ 
[112]. However, the presence of a hypermucoviscous phenotype has also been reported in the absence of these genes $[113,114]$. The correlation between CPS production and hypermucoviscosity was investigated further by Mike and colleagues [115]. The authors demonstrated a statistical link between CPS and hypermucoviscosity but also found that certain gene mutations dissociate this relationship. Russo et al. [9] identified iucA, iroB, rmpA, $r m p A 2$, and $p e g-334$ as gene biomarkers that differentiate $\mathrm{hvHp}$ from $\mathrm{cKp}$ clinical isolates. In general, the presence of $r m p A, r m p A 2$, and genes-encoding 2 siderophores aerobactin (iuc) and salmochelin (iro) - are predictors for the hvKp pathotype [116-118]. Siderophores are secreted small molecules used by microorganisms to scavenge iron from the host environment $[119,120]$. K. pneumoniae aerobactin, salmochelin, and yersiniabactin are encoded on mobile genetic elements, whereas the conserved siderophore enterobactin is encoded within the core genome [121, 122]. Although multiple iron uptake systems can contribute to K. pneumoniae virulence [123], Russo et al. [9] demonstrated that aerobactin alone contributes to hvKp survival in human serum and virulence in mouse infection models $[124,125]$.

Klebsiella spp. can produce multiple surface molecules that facilitate adhesion and attachment to host tissues [126-129]. K. pneumoniae type I fimbriae exhibit a mannose-sensitive adhesion phenotype and are closely related to other Enterobacteriaceae type I fimbriae [130, 131]. They are an important virulence factor in urinary tract infections and facilitate binding to the epithelial cells of the urogenital tract [132]. Type I fimbriae are characterized by the bacterial fim switch system that is turned "on" or "off" based on cues from the extracellular environment. In liquid broth culture and during urinary tract infection, the switch system is "on," whereas in static culture or during gastrointestinal tract colonization, the fim switch is "off" [132]. Type III fimbriae proteins known as MrkA and MrkD play a distinct role in mediating adhesion and biofilm formation on the extracellular matrix, collagen (MrkD), and abiotic (MrkA) surfaces [133, 134]. Type III fimbriae drive initial cell surface attachment as well as cell-cell adhesion during biofilm formation [129]. In addition to these molecules, Di Martino et al. [135, 136] discovered a K. pneumoniae fimbria named KPF- 28 and a nonfimbrial adhesin known as CF29K that each promotes binding of $K$. pneumoniae to Caco-2 and Intestine-407 cells in vitro.

Recent genome-scale screens have also led to the identification of bacterial factors that are essential for survival of K. pneumoniae in the host and/or contribute to patho- genesis. For example, Bachman et al. [60] used a transposon insertion site sequencing approach to identify $>300$ genes in the hvKp strain KPPR1 (a derivative of 43816) that contribute bacterial growth and/or survival in a mouse pneumonia model. More recently, Paczosa et al. [137] used transposon sequencing to identify K. pneumoniae molecules that are required for survival in the mouse lung, including several that protect from neutrophil-mediated killing. Such transposon sequencing approaches are becoming more widely used to identify molecules that contribute to bacterial fitness or virulence in vivo [138-145]. These approaches, combined with appropriate animal infection models, can accelerate identification of new targets for therapeutics and vaccines [146, 147].

Designing animal infection models to mimic human disease caused by opportunistic pathogens such as ST258 presents numerous challenges. Healthy mice are relatively resistant to infection caused by ST258, and development of morbidity requires a very high inoculum [110, 148]. This point was demonstrated further by Sequeira et al. [149] who showed a diminished ability of ST258 to colonize the gastrointestinal tract of mice with an established and healthy microbiome. One option is to employ a naturally susceptible animal to model Klebsiella infections. Nonhuman primates are naturally susceptible to Klebsiella, which manifests primarily as a pulmonary infection [150]. Cynomolgus macaques develop severe lung pathology consistent with bronchiolitis obliterans organizing pneumonia when infected with ST258 [151]. In addition, nonhuman primate lung and airway anatomy are closely related to that of humans. Dumigan et al. [152] used a porcine ex vivo lung perfusion model that closely recapitulated changes observed in human lungs due to infection with $K$. pneumoniae. However, using large animal models has significant challenges and there are additional ethical considerations. Another option to increase animal susceptibility to infection is pretreatment with drugs (typically drugs used for cancer treatment or transplant antirejection drugs) to induce an immunocompromised state. Alternatively, there are murine knockouts and knock-in strains available that mimic various immune system deficiencies. In a recent study by Iwanaga et al. [153], the authors utilized a murine Rag2 $2^{-/-}$ and $\mathrm{Rag}^{-/-} \mathrm{Il}_{2 \mathrm{rg}^{-/-}}$pulmonary infection model to evaluate the host immune factors that are important during bacterial infection. Subsequently, the authors developed a more clinically relevant immunocompromised animal model by treating wild-type C57BL/6 mice with the calcineurin inhibitor FK506 (transplant antirejection drug). 
Fig. 2. Vaccines and therapeutic approaches for prevention and treatment of K. pneumoniae infections. CPS, capsule polysaccharide.

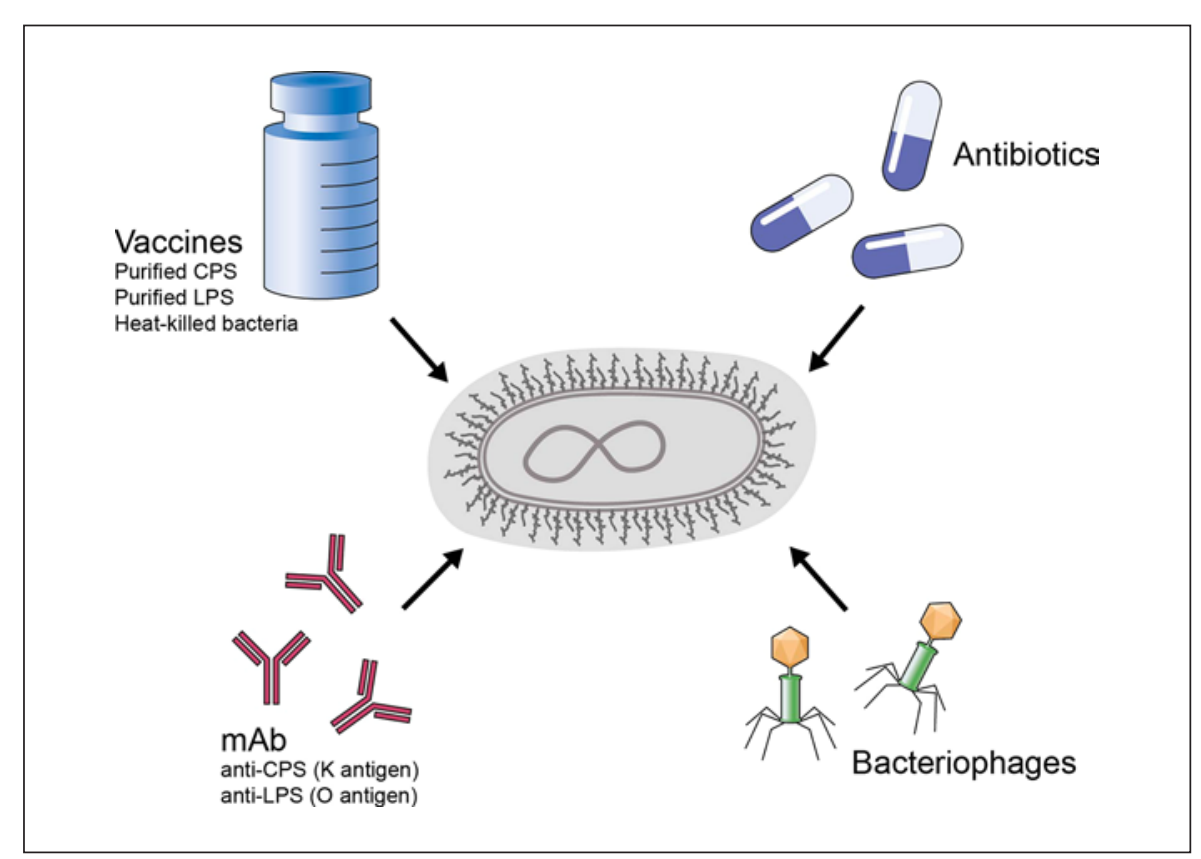

Animal models such as those presented by Iwanaga et al. [153] are a step toward developing adequate models with which to test therapeutic and immunoprophylactic approaches for treating and preventing K. pneumoniae infections.

\section{Vaccines and Novel Therapeutic Approaches}

Increasing antibiotic resistance among $K$. pneumoniae and the presence of MDR isolates necessitated development of alternative approaches for prevention and treatment of infections, including passive antibody-based therapy approaches and active vaccination (Fig. 2). Antibody-based immunotherapeutics or immunoprophylactic use of vaccines presents several advantages over the use of antibiotics alone. For example, designing antibodies that target only K. pneumoniae epitopes could potentially eliminate the pathogen and spare beneficial bacteria that constitute a healthy microbiome [154]. In vitro and in vivo studies indicate the use of specific antibodies dramatically increases uptake and killing of $K$. pneumoniae by immune cells, which consequently leads to improved recovery and increased survival in animal infection models [96-98, 151]. Diago-Navarro et al. [155] generated mAbs specific for the CPS of an ST23 hvKp strain (K1 capsule serotype) and then demonstrated the ability of these $\mathrm{mAbs}$ to protect against bacterial dissemination in a mouse infection model. This research group used a similar approach to test the ability of mAbs specific for CPS glycoconjugates derived from ST258 clade 1 and 2 strains to promote opsonophagocytosis in vitro and reduce bacterial dissemination in a mouse infection model [96]. Cohen et al. [156] used mAbs specific for K. pneumoniae LPS to show protection against death in a mouse model of acute pneumonia caused by LPS serotype $\mathrm{O} 1$ or O $2 \mathrm{~K}$. pneumoniae strains. These anti-LPS mAbs protected mice against lethal pneumonia when added before or after inoculation [156]. Studies by Pennini et al. [157] identified human mAbs specific for $\mathrm{O} 1$ and/or $\mathrm{O} 2$ antigens and found that these antibodies combined with antibiotics protected mice against death caused by MDR K. pneumoniae strains. Notably, this study also revealed a relative paucity of human antibody specific for serotype O2 LPS, which may explain in part the higher prevalence of MDR clones that express the O2-antigen (e.g., ST258) [157]. Collectively, these studies underscore the therapeutic potential of mAbs specific for K. pneumoniae CPS and LPS.

Bacterial vaccines can be categorized as (i) live attenuated or inactivated/killed vaccines that utilize live attenuated bacteria or dead bacteria, respectively; (ii) toxoid vaccines based on the use of inactivated bacterial toxins; and (iii) subunit (including conjugated) vaccines using only certain parts of the pathogen they are directed against [158]. The use of killed or live attenuated bacteria often offers broad immunity toward a variety of bacterial epi- 
topes. As an example, inactivated K. pneumoniae is one of 4 bacterial strains used in the Uromune ${ }^{\circledR}$ vaccine that currently is undergoing phase 2 clinical trials for use in patients with recurrent urinary tract infections $[159,160]$. This vaccine is administered via the sublingual route, and results to date indicate it is safe and effective at preventing recurring urinary tract infections $[159,161]$. Moreover, use of heat-killed bacteria in a murine pneumonia model induces a strong Th17-dependent immune response that confers protection during subsequent challenge [162]. $K$. pneumoniae-derived outer membrane vesicles (also known as extracellular vesicles) are intriguing vaccine antigens with potential to elicit broad protective immunity. These spherical nanoparticles are secreted by Gram-negative bacteria and comprise bacterial periplasm and outer membrane that includes LPS and other membrane-associated virulence factors $[163,164]$. Preliminary studies have shown that vaccination with outer membrane vesicles, although dose-dependent, can confer complete protection from severe or fatal disease in mouse bacteremia models [104, 165].

When considering more targeted bacterial epitopes for subunit vaccines, $K$. pneumoniae molecules of interest are typically CPS, LPS, or bacterial proteins (Fig. 2). CPS has been used successfully in highly effective meningococcal and pneumococcal vaccines $[166,167]$. Hence, it is one of the more obvious targets for immunotherapy and prophylaxis against K. pneumoniae infections. Indeed, a multivalent vaccine containing CPS from several different $K$. pneumoniae serotypes was evaluated as a potential vaccine candidate in the 1980s and 1990s, including efficacy and safety testing in humans $[66,67,168]$. Immunogenicity of CPS can be improved significantly by coupling the molecule with a carrier protein, typically an inactivated bacterial toxin. Recently, Feldman et al. [169] used E. coli for heterologous expression of CPS from serotypes K1 and K2 hvKp strains (NTUH K2044 and ATCC 43816) and exotoxin A protein from Pseudomonas aeruginosa as a means to develop a bioconjugate vaccine. The purified K1- and K2-exotoxin A bioconjugates protected mice against lethal infection caused by K1 or K2 strains [169]. Seeberger at al. used a semisynthetic approach to generate glycoconjugate vaccine antigens that elicit CPS-specific antibodies [170]. Notably, these antibodies were crossreactive with CPS on the surface of several carbapenemresistant $K$. pneumoniae isolates tested, underscoring the potential for greater strain coverage [170]. Hegerle et al. [171] reported development of a glycoconjugate vaccine based upon K. pneumoniae $\mathrm{O}$-antigens (4 most common O types) and $P$. aeruginosa flagellin. This vaccine utilized
O-antigens chemically linked to flagellin and elicited antibodies that have the potential to confer broad protection against $K$. pneumoniae or $P$. aeruginosa infections.

A well-recognized limitation of CPS-specific vaccines is that there is a relatively high degree of variability in CPS structures among K. pneumoniae isolates [44], which presents a challenge for vaccine coverage. Incorporation of more conserved bacterial protein targets may mitigate some of these issues. To this end, Wang et al. [172] demonstrated that antibody generated against MrkA (type III fimbrial protein) reduced bacteria attachment and biofilm formation in vitro and protected mice against lethal pneumonia in a K. pneumoniae infection model. Siderophore receptor protein is another conserved protein that has been tested as a potential vaccine candidate. Gorden et al. [173] reported that the use of this protein as a vaccine candidate, to aid with clinical mastitis due to Klebsiella spp. in cows, reduced the risk of mastitis by almost $77 \%$ if administered before calving. Omps have also shown promise as potential vaccine candidates. A recombinant multi-epitope vaccine ( $\mathrm{r}$-AK36) comprising domains from OmpA and Omp36K protected mice from death in a K. pneumoniae infection model [174]. Moreover, antibodies specific for $\mathrm{r}$-AK36 conferred significant protection to mice when administered prior to $K$. pneumoniae infection [174]. Taken together, these studies demonstrate the merit of immunoprophylactic and immunotherapeutic approaches for the prevention and treatment of infections caused by MDR K. pneumoniae.

Aside from targeting bacterial epitopes directly, several research groups have shown that altering or blocking the function of host immune molecules has potential to aid in more efficient resolution of infection. This strategy is typically geared toward moderating the host immune response to prevent self-propelled damage to the tissue during infection. TLR3 is one such host molecule that has been considered as a therapeutic target. Although typically considered as a viral pattern recognition receptor, TLR3 plays a role in driving an inflammatory response by sensing ds-RNA from necrotic cells [175]. Interestingly, antibody-mediated neutralization of TLR3 increased animal survival in a murine $K$. pneumoniaepneumonia model [176]. Moreover, direct modification of IgG molecules, specifically multiplications of the antibody Fc domain, bolsters antibacterial potential significantly by increasing opsonophagocytic killing of bacteria and increased animal survival in a lethal pneumonia model, compared to the parental antibody [177].

In addition to antibody and vaccine approaches, there is also a renewed interest in the use of bacteriophages 
(phages) for treatment of severe bacterial infections [178181]. Phages are bacterial viruses that infect and, in case of lytic phages, subsequently lyse bacterial cells [182]. Although very sporadic and more as a compassionate use option, phage therapy has been used in patients with a promising outcome $[181,183]$. As one of the more recent examples, intravenous phage administration along with oral minocycline was successfully used to treat a prosthetic knee joint infection due to K. pneumoniae, with full recovery of the patient [184]. Nonetheless, phage therapy has its own shortcomings. Inherent phage specificity - although advantageous while precisely targeting bacterial strains - can implement constraints when searching for cluding $K$. pneumoniae are capable of developing resistance toward phage, which potentially can limit the use of mono-phage therapy in treatment of bacterial infections [186]. More work is needed to optimize the utility and therapeutic potential of phage therapy. This includes developing approaches that address the problem of bacterial resistance to phage and translation of phage therapy results obtained from animal infection models to applications in humans [187].

The shrinking repertoire of available antibiotics and paucity of new antibiotics to treat infections caused by MDR bacteria, together with the ability of bacteria to readily acquire antibiotic resistance, have pushed researchers and pharmaceutical companies to consider alternative approaches to treat bacterial infections. Development of a successful vaccine or use of antibody or phage therapy has the potential to reduce antibiotic pressure on bacteria and subsequently would lessen a need for bacteria to acquire antibiotic resistance. Nonetheless, development of a vaccine for $K$. pneumoniae has been (and is) challenging, as there is a relatively narrow market group and a need for precise identification of target populations that potentially could benefit from such a vaccine. Currently, there is no license vaccine available for K. pneumoniae in the USA. Each of these novel treatment strategies is still in the early development or preclinical stage, and more research is needed to evaluate the potential benefits and applicability of it in humans (Fig. 2).

\section{Concluding Remarks}

Prevention and treatment of infections caused by opportunistic pathogens such as $K$. pneumoniae remain a significant challenge in large part because host defense in optimal phage treatment [185]. Additionally, bacteria in-

the susceptible individual is insufficient to protect against severe disease and because such microbes are often MDR. New therapeutic approaches and vaccines, including targeted $\mathrm{mAb}$ therapies and CPS or LPS-specific vaccines, show promise, but more work is needed in these areas. Notably, it will be important to develop animal infection models that more closely mimic human susceptibilities to lineages of $K$. pneumoniae that are opportunistic pathogens.

\section{Acknowledgment}

The authors are grateful to Visual Medical Arts (NIAID Rocky Mountain Laboratories, Hamilton, MT, USA) for assistance with preparation of illustrations.

\section{Conflict of Interest Statement}

The authors have no conflicts of interest to declare.

\section{Funding Sources}

The authors are supported by the Intramural Research Program of the National Institute of Allergy and Infectious Diseases, National Institutes of Health.

\section{Author Contributions}

C.O.-T., N.M., S.D.K., and F.R.D. wrote the manuscript.
References
1 Podschun R, Ullmann U. Klebsiella spp. as nosocomial pathogens: epidemiology, taxonomy, typing methods, and pathogenicity factors. Clin Microbiol Rev. 1998 Oct;11(4):589603.

2 Pomakova DK, Hsiao CB, Beanan JM, Olson $\mathrm{R}$, MacDonald U, Keynan Y, et al. Clinical and phenotypic differences between classic and hypervirulent Klebsiella pneumonia: an emerging and under-recognized pathogenic variant. Eur J Clin Microbiol Infect Dis. 2012 Jun;31(6):981-9.

3 Russo TA, Marr CM. Hypervirulent Klebsiella pneumoniae. Clin Microbiol Rev. 2019 Jun 19;32(3):e00001-19.

4 Diekema DJ, Hsueh PR, Mendes RE, Pfaller MA, Rolston KV, Sader HS, et al. The microbiology of bloodstream infection: 20-year trends from the SENTRY antimicrobial surveillance program. Antimicrob Agents Chemother. 2019 Jul;63(7):e00355-19. 
5 Paczosa MK, Mecsas J. Klebsiella pneumoniae: going on the offense with a strong defense. Microbiol Mol Biol Rev. 2016;80(3):629-61.

6 Shon AS, Bajwa RP, Russo TA. Hypervirulent (hypermucoviscous) Klebsiella pneumoniae: a new and dangerous breed. Virulence. 2013 Feb;4(2):107-18.

7 Liu YC, Cheng DL, Lin CL. Klebsiella pneumoniae liver abscess associated with septic endophthalmitis. Arch Intern Med. 1986 Oct; 146(10):1913-6.

8 Chiu CT, Lin DY, Liaw YF. Metastatic septic endophthalmitis in pyogenic liver abscess. J Clin Gastroenterol. 1988 Oct;10(5):524-7.

9 Russo TA, Olson R, Fang CT, Stoesser N, Miller M, MacDonald U, et al. Identification of biomarkers for differentiation of hypervirulent Klebsiella pneumoniae from classical $\mathrm{K}$. pneumoniae. J Clin Microbiol. 2018;56(9): e00776-18.

10 Chen YT, Chang HY, Lai YC, Pan CC, Tsai SF, Peng HL. Sequencing and analysis of the large virulence plasmid pLVPK of Klebsiella pneumoniae CG43. Gene. 2004 Aug;337:18998.

11 Choby JE, Howard-Anderson J, Weiss DS. Hypervirulent Klebsiella pneumoniae - clini$\mathrm{cal}$ and molecular perspectives. J Intern Med. 2020;287(3):283-300.

12 Harada S, Aoki K, Yamamoto S, Ishii Y, Sekiya $\mathrm{N}$, Kurai $\mathrm{H}$, et al. Clinical and molecular characteristics of Klebsiella pneumoniae isolates causing bloodstream infections in Japan: occurrence of hypervirulent infections in health care. J Clin Microbiol. 2019 Nov; 57(11):e01206-19.

13 Liu C, Du P, Xiao N, Ji F, Russo TA, Guo J. Hypervirulent Klebsiella pneumoniae is emerging as an increasingly prevalent $\mathrm{K}$. pneumoniae pathotype responsible for nosocomial and healthcare-associated infections in Beijing, China. Virulence. 2020;11(1): 1215-24.

14 Wyres KL, Lam MMC, Holt KE. Population genomics of Klebsiella pneumoniae. Nat Rev Microbiol. 2020;18(6):344-59.

15 Campos M, Antunes LC, Ferreira RB. Global priority pathogens: virulence, antimicrobial resistance and prospective treatment options. Future Microbiol. 2020;15:649-77.

16 De Oliveira DMP, Forde BM, Kidd TJ, Harris PNA, Schembri MA, Beatson SA, et al. Antimicrobial resistance in ESKAPE pathogens. Clin Microbiol Rev. 2020 Jun 17;33(3): e00181-19.

17 Calbo E, Garau J. The changing epidemiology of hospital outbreaks due to ESBL-producing Klebsiella pneumoniae: the CTX-M-15 type consolidation. Future Microbiol. 2015;10(6): 1063-75.

18 Yigit $\mathrm{H}$, Queenan AM, Anderson GJ, Domenech-Sanchez A, Biddle JW, Steward $\mathrm{CD}$, et al. Novel carbapenem-hydrolyzing beta-lactamase, KPC-1, from a carbapenem-resistant strain of Klebsiella pneumoniae. Antimicrob Agents Chemother. 2001 Apr;45(4): 1151-61.
19 Peirano G, Bradford PA, Kazmierczak KM, Chen L, Kreiswirth BN, Pitout JD. Importance of clonal complex 258 and IncFK2-like plasmids among a global collection of Klebsiella pneumoniae with blaKPC. Antimicrob Agents Chemother. 2017 Apr;61(4):e02610 16.

20 van Duin D, Arias CA, Komarow L, Chen L, Hanson BM, Weston G, et al. Molecular and clinical epidemiology of carbapenem-resistant Enterobacterales in the USA (CRACKLE-2): a prospective cohort study. Lancet Infect Dis. 2020;20(6):731-41.

21 Jernigan JA, Hatfield KM, Wolford $\mathrm{H}$, Nelson RE, Olubajo B, Reddy SC, et al. Multidrugresistant bacterial infections in US2 hospitalized patients, 2012-2017. N Engl J Med. 2020; 382(14):1309-19.

22 da Silva RM, Traebert J, Galato D. Klebsiella pneumoniae carbapenemase (KPC)-producing Klebsiella pneumoniae: a review of epidemiological and clinical aspects. Expert Opin Biol Ther. 2012 Jun;12(6):663-71.

23 Jernigan MG, Press EG, Nguyen MH, Clancy CJ, Shields RK. The combination of doripen$\mathrm{em}$ and colistin is bactericidal and synergistic against colistin-resistant, carbapenemaseproducing Klebsiella pneumoniae. Antimicrob Agents Chemother. 2012 Jun;56(6): 3395-8.

24 Lopez-Camacho E, Gomez-Gil R, Tobes R, Manrique M, Lorenzo M, Galvan B, et al. Genomic analysis of the emergence and evolution of multidrug resistance during a Klebsiella pneumoniae outbreak including carbapenem and colistin resistance. J Antimicrob Chemother. 2014 Mar;69(3):632-6.

25 van Duin D, Cober ED, Richter SS, Perez F, Cline M, Kaye KS, et al. Tigecycline therapy for carbapenem-resistant Klebsiella pneumoniae (CRKP) bacteriuria leads to tigecycline resistance. Clin Microbiol Infect. 2014 Dec;20(12):O1117-20.

26 Parisi SG, Bartolini A, Santacatterina E, Castellani E, Ghirardo R, Berto A, et al. Prevalence of Klebsiella pneumoniae strains producing carbapenemases and increase of resistance to colistin in an Italian teaching hospital from January 2012 to December 2014. BMC Infect Dis. 2015 Jun 27;15:244.

27 Mmatli M, Mbelle NM, Maningi NE, Osei Sekyere J. Emerging transcriptional and genomic mechanisms mediating carbapenem and polymyxin resistance in Enterobacteriaceae: a systematic review of current reports. mSystems. 2020 Dec 15;5(6):e00783-20.

28 Zhang X, Qu F, Jia W, Huang B, Shan B, Yu $\mathrm{H}$, et al. Polymyxin resistance in carbapenemresistant Enterobacteriaceae isolates from patients without polymyxin exposure: a multicentre study in China. Int $J$ Antimicrob Agents. $2021 \mathrm{Feb} ; 57(2): 106262$.

$29 \mathrm{Du} \mathrm{H}$, Chen L, Tang YW, Kreiswirth BN. Emergence of the mcr-1 colistin resistance gene in carbapenem-resistant Enterobacteriaceae. Lancet Infect Dis. 2016 Mar;16(3):2878.
30 Liu YY, Wang Y, Walsh TR, Yi LX, Zhang R, Spencer J, et al. Emergence of plasmid-mediated colistin resistance mechanism MCR-1 in animals and human beings in China: a microbiological and molecular biological study. Lancet Infect Dis. 2016 Feb;16(2):161-8.

31 Wang X, Wang Y, Zhou Y, Li J, Yin W, Wang $\mathrm{S}$, et al. Emergence of a novel mobile colistin resistance gene, mcr-8, in NDM-producing Klebsiella pneumoniae. Emerg Microbes Infect. 2018 Jul 4;7(1):122.

32 van Duin D, Lok JJ, Earley M, Cober E, Richter SS, Perez F, et al. Colistin versus ceftazidime-avibactam in the treatment of infections due to carbapenem-resistant Enterobacteriaceae. Clin Infect Dis. 2018;66(2):163-71.

33 Doi Y. Treatment options for carbapenemresistant gram-negative bacterial infections. Clin Infect Dis. 2019 11;69(Suppl 7):S565-75.

34 Pogue JM, Bonomo RA, Kaye KS. Ceftazidime/avibactam, meropenem/vaborbactam, or both? Clinical and formulary considerations. Clin Infect Dis. 2019;68(3):51924.

35 Shields RK, Chen L, Cheng S, Chavda KD, Press EG, Snyder A, et al. Emergence of ceftazidime-avibactam resistance due to plasmid-borne blaKPC-3 mutations during treatment of carbapenem-resistant Klebsiella pneumoniae infections. Antimicrob Agents Chemother. 2017 Mar;61(3):e02097-16.

36 Lee CR, Lee JH, Park KS, Jeon JH, Kim YB, Cha CJ, et al. Antimicrobial resistance of hypervirulent Klebsiella pneumoniae: epidemiology, hypervirulence-associated determinants, and resistance mechanisms. Front Cell Infect Microbiol. 2017;7:483.

37 Chen L, Kreiswirth BN. Convergence of carbapenem-resistance and hypervirulence in Klebsiella pneumoniae. Lancet Infect Dis. 2018;18(1):2-3.

38 Karlsson M, Stanton RA, Ansari U, McAllister G, Chan MY, Sula E, et al. Identification of a carbapenemase-producing hypervirulent Klebsiella pneumoniae isolate in the United States. Antimicrob Agents Chemother. 2019; 63(7):e00519-19.

39 Lai YC, Lu MC, Hsueh PR. Hypervirulence and carbapenem resistance: two distinct evolutionary directions that led high-risk. Expert Rev Mol Diagn. 2019;19(9):825-37.

40 Lin YT, Cheng YH, Chuang C, Chou SH, Liu $\mathrm{WH}$, Huang $\mathrm{CH}$, et al. Molecular and clinical characterization of multidrug-resistant and hypervirulent Klebsiella pneumoniae strains from liver abscess in Taiwan. Antimicrob Agents Chemother. 2020;64(5):e00174-20.

41 Bain W, Li H, van der Geest R, Moore SR, Olonisakin TF, Ahn B, et al. Increased alternative complement pathway function and improved survival during critical illness. Am J Respir Crit Care Med. 2020 Jul 15;202(2): 230-40.

42 Amako K, Meno Y, Takade A. Fine structures of the capsules of Klebsiella pneumoniae and Escherichia coli K1. J Bacteriol. 1988 Oct; 170(10):4960-2. 
43 Pan YJ, Lin TL, Chen CT, Chen YY, Hsieh PF, Hsu CR, et al. Genetic analysis of capsular polysaccharide synthesis gene clusters in 79 capsular types of Klebsiella spp. Sci Rep. 2015 Oct; $5: 15573$.

44 Follador R, Heinz E, Wyres KL, Ellington MJ, Kowarik M, Holt KE, et al. The diversity of Klebsiella pneumoniae surface polysaccharides. Microb Genom. 2016 Aug;2(8):e000073.

45 Brisse S, Passet V, Haugaard AB, Babosan A, Kassis-Chikhani N, Struve C, et al. wzi gene sequencing, a rapid method for determination of capsular type for Klebsiella strains. J Clin Microbiol. 2013 Dec;51(12):4073-8.

46 Chen L, Chavda KD, Findlay J, Peirano G, Hopkins K, Pitout JD, et al. Multiplex PCR for identification of two capsular types in epidemic KPC-producing Klebsiella pneumoniae sequence type 258 strains. Antimicrob Agents Chemother. 2014 Jul;58(7):4196-9.

47 Diago-Navarro E, Chen L, Passet V, Burack S, Ulacia-Hernando A, Kodiyanplakkal RP, et al. Carbapenem-resistant Klebsiella pneumoniae exhibit variability in capsular polysaccharide and capsule associated virulence traits. J Infect Dis. 2014 Sep 1;210(5):803-13.

48 Wyres KL, Wick RR, Gorrie C, Jenney A, Follador R, Thomson NR, et al. Identification of Klebsiella capsule synthesis loci from whole genome data. Microb Genom. 2016 Dec; 2(12): $\mathrm{e} 000102$

49 Wick RR, Heinz E, Holt KE, Wyres KL. Kaptive web: user-friendly capsule and lipopolysaccharide serotype prediction for Klebsiella genomes. J Clin Microbiol. 2018 Jun;56(6): e00197-18.

50 Albertí S, Marqués G, Camprubí S, Merino S, Tomás JM, Vivanco F, et al. C1q binding and activation of the complement classical pathway by Klebsiella pneumoniae outer membrane proteins. Infect Immun. 1993 Mar; 61(3):852-60.

51 Albertí S, Marqués G, Hernández-Allés S, Rubires X, Tomás JM, Vivanco F, et al. Interaction between complement subcomponent $\mathrm{C} 1 \mathrm{q}$ and the Klebsiella pneumoniae porin OmpK36. Infect Immun. 1996 Nov;64(11): 4719-25.

52 Fang CT, Chuang YP, Shun CT, Chang SC, Wang JT. A novel virulence gene in Klebsiella pneumoniae strains causing primary liver abscess and septic metastatic complications. J Exp Med. 2004 Mar;199(5):697-705.

53 Cortés G, Borrell N, de Astorza B, Gómez C, Sauleda J, Albertí S. Molecular analysis of the contribution of the capsular polysaccharide and the lipopolysaccharide $\mathrm{O}$ side chain to the virulence of Klebsiella pneumoniae in a murine model of pneumonia. Infect Immun. 2002 May;70(5):2583-90.

54 Domenico P, Tomas JM, Merino S, Rubires X, Cunha BA. Surface antigen exposure by bismuth dimercaprol suppression of Klebsiella pneumoniae capsular polysaccharide. Infect Immun. 1999 Feb;67(2):664-9.

55 Jensen TS, Opstrup KV, Christiansen G, Rasmussen PV, Thomsen ME, Justesen DL, et al.
Complement mediated Klebsiella pneumoniae capsule changes. Microbes Infect. 2020 Jan-Feb;22(1):19-30.

56 Merino S, Camprubí S, Albertí S, Benedí VJ, Tomás JM. Mechanisms of Klebsiella pneumoniae resistance to complement-mediated killing. Infect Immun. 1992 Jun;60(6):252935.

57 Ciurana B, Tomás JM. Role of lipopolysaccharide and complement in susceptibility of Klebsiella pneumoniae to nonimmune serum. Infect Immun. 1987 Nov;55(11):27416.

58 Hsieh PF, Liu JY, Pan YJ, Wu MC, Lin TL, Huang YT, et al. Klebsiella pneumoniae peptidoglycan-associated lipoprotein and murein lipoprotein contribute to serum resistance, antiphagocytosis, and proinflammatory cytokine stimulation. J Infect Dis. 2013 Nov;208(10):1580-9.

59 Short FL, Di Sario G, Reichmann NT, Kleanthous C, Parkhill J, Taylor PW. Genomic profiling reveals distinct routes to complement resistance in Klebsiella pneumoniae. Infect Immun. $2020 \mathrm{Jul} ; 88(8): \mathrm{e} 00043-20$.

60 Bachman MA, Breen P, Deornellas V, Mu Q, Zhao L, Wu W, et al. Genome-wide identification of Klebsiella pneumoniae fitness genes during lung infection. mBio. 2015 Jun;6(3): e00775.

61 Sawyer WD, Smith MR, Wood WB Jr. The mechanisms by which macrophages phagocyte encapsulated bacteria in the absence of antibody. J Exp Med. 1954 Oct 1;100(4):417-24.

62 Hall HE, Humphries JC. The relationship between insusceptibility to phagocytosis and virulence of certain Klebsiella pneumoniae strains. J Infect Dis. 1958 Sep-Oct;103(2): $157-62$.

63 Wood WB Jr, Smith MR. Intercellular surface phagocytosis. Science. 1947 Jul 25;106(2743): 86-7.

64 Wood WB Jr. Phagocytosis, with particular reference to encapsulated bacteria. Bacteriol Rev. 1960 Mar;24(1):41-9.

65 Leist-Welsh P, Bjornson AB. Requirements of immunoglobulin and the classical and alternative complement pathways for phagocytosis and intracellular killing of multiple strains of Gram-negative aerobic bacilli. Infect Immun. 1979 Oct;26(1):99-109.

66 Cryz SJ, Fürer E, Germanier R. Safety and immunogenicity of Klebsiella pneumoniae K1 capsular polysaccharide vaccine in humans. J Infect Dis. 1985 Apr;151(4):665-71.

67 Donta ST, Peduzzi P, Cross AS, Sadoff J, Haakenson C, Cryz SJ, et al. Immunoprophylaxis against klebsiella and pseudomonas aeruginosa infections. The Federal Hyperimmune Immunoglobulin Trial Study Group. J Infect Dis. 1996 Sep;174(3):537-43.

68 Smith MR, Wood WB. Studies on the mechanism of recovery in pneumonia due to Friedlander's Bacillus: III. The role of "surface phagocytosis" in the destruction of the microorganisms in the lung. J Exp Med. 1947 Aug 31;86(3):257-66.
69 Cano V, March C, Insua JL, Aguiló N, Llobet E, Moranta D, et al. Klebsiella pneumoniae survives within macrophages by avoiding delivery to lysosomes. Cell Microbiol. $2015 \mathrm{Nov}$; 17(11):1537-60.

70 Bullen JJ, Leach PA, Lange L. Abolition of resistance to Klebsiella pneumoniae by antipolymorphonuclear leucocyte IgG. Immunology. 1980 Jan;39(1):47-52.

71 Ye P, Rodriguez FH, Kanaly S, Stocking KL, Schurr J, Schwarzenberger P, et al. Requirement of interleukin 17 receptor signaling for lung CXC chemokine and granulocyte colony-stimulating factor expression, neutrophil recruitment, and host defense. J Exp Med. 2001 Aug;194(4):519-27.

72 Xiong H, Carter RA, Leiner IM, Tang YW, Chen L, Kreiswirth BN, et al. Distinct contributions of neutrophils and CCR2+ monocytes to pulmonary clearance of different Klebsiella pneumoniae strains. Infect Immun. 2015 Sep;83(9):3418-27.

73 Nguyen GT, Shaban L, Mack M, Swanson $\mathrm{KD}$, Bunnell SC, Sykes DB, et al. SKAP2 is required for defense against $\mathrm{K}$. pneumoniae infection and neutrophil respiratory burst. Elife. 2020;9:e56656.

74 Belaaouaj A, McCarthy R, Baumann M, Gao Z, Ley TJ, Abraham SN, et al. Mice lacking neutrophil elastase reveal impaired host defense against gram negative bacterial sepsis. Nat Med. 1998 May;4(5):615-8.

75 Hirche TO, Gaut JP, Heinecke JW, Belaaouaj A. Myeloperoxidase plays critical roles in killing Klebsiella pneumoniae and inactivating neutrophil elastase: effects on host defense. J Immunol. 2005 Feb;174(3):1557-65.

76 Umsawasdi T, Middleman EA, Luna M, Bodey GP. Klebsiella bacteremia in cancer patients. Am J Med Sci. 1973 Jun;265(6):473-82.

77 Satlin MJ, Calfee DP, Chen L, Fauntleroy KA, Wilson SJ, Jenkins SG, et al. Emergence of carbapenem-resistant Enterobacteriaceae as causes of bloodstream infections in patients with hematologic malignancies. Leuk Lymphoma. 2013 Apr;54(4):799-806.

78 Satlin MJ, Cohen N, Ma KC, Gedrimaite Z, Soave R, Askin G, et al. Bacteremia due to carbapenem-resistant Enterobacteriaceae in neutropenic patients with hematologic malignancies. J Infect. 2016 Oct;73(4):336-45.

79 Fukutome T, Mitsuyama M, Takeya K, Nomoto K. Importance of antiserum and phagocytic cells in the protection of mice against infection by Klebsiella pneumoniae. J Gen Microbiol. 1980 Jul;119(1):225-9.

80 Yokota Y, Wakai Y, Mine Y, Goto S, Nishida M, Kuwahara S. Degradation of host defenses against respiratory tract infection by Klebsiella pneumoniae in aged mice. Infect Immun. 1988 Apr;56(4):966-71.

81 Melissen PM, van Vianen W, Bakker-Woudenberg IA. Roles of peripheral leukocytes and tissue macrophages in antibacterial resistance induced by free or liposome-encapsulated muramyl tripeptide phosphatidylethanolamide. Infect Immun. 1992 Nov;60(11):4891-7. 
82 Broug-Holub E, Toews GB, van Iwaarden JF, Strieter RM, Kunkel SL, Paine R 3rd, et al. Alveolar macrophages are required for protective pulmonary defenses in murine Klebsiella pneumonia: elimination of alveolar macrophages increases neutrophil recruitment but decreases bacterial clearance and survival. Infect Immun. 1997 Apr;65(4):1139-46.

83 Mancuso P, Standiford TJ, Marshall T, PetersGolden M. 5-Lipoxygenase reaction products modulate alveolar macrophage phagocytosis of Klebsiella pneumoniae. Infect Immun. 1998 Nov;66(11):5140-6.

84 Hickman-Davis JM, O 'Reilly P, Davis IC, Peti-Peterdi J, Davis G, Young KR, et al. Killing of Klebsiella pneumoniae by human alveolar macrophages. Am J Physiol Lung Cell Mol Physiol. 2002 May;282(5):L944-56.

85 Bhan U, Lukacs NW, Osterholzer JJ, Newstead MW, Zeng X, Moore TA, et al. TLR9 is required for protective innate immunity in Gram-negative bacterial pneumonia: role of dendritic cells. J Immunol. 2007 Sep;179(6): 3937-46.

86 Xiong H, Keith JW, Samilo DW, Carter RA, Leiner IM, Pamer EG. Innate lymphocyte/ Ly6C(hi) monocyte crosstalk promotes Klebsiella pneumoniae clearance. Cell. 2016 Apr; 165(3):679-89.

87 Ivin M, Dumigan A, de Vasconcelos FN, Ebner F, Borroni M, Kavirayani A, et al. Natural killer cell-intrinsic type I IFN signaling controls Klebsiella pneumoniae growth during lung infection. PLoS Pathog. 2017 Nov; 13(11):e1006696.

88 Greenberger MJ, Strieter RM, Kunkel SL, Danforth JM, Laichalk LL, McGillicuddy DC, et al. Neutralization of macrophage inflammatory protein- 2 attenuates neutrophil recruitment and bacterial clearance in murine Klebsiella pneumonia. J Infect Dis. 1996 Jan; 173(1):159-65.

89 Iida-Tanaka K, Tanaka T, Irino S, Nagayama A. Enhanced bactericidal action of mouse macrophages by subinhibitory concentrations of monobactams. J Antimicrob Chemother. 1986 Aug;18(2):239-50.

90 Cuffini AM, Tullio V, Fazari S, Paizis G, Carlone NA. The effects of sub-MICs of cefonicid on the interaction of human macrophages with Klebsiella pneumoniae. J Antimicrob Chemother. 1991 Dec;28(6):933-5.

91 Nomura S, Murata K, Nagayama A. Effects of sub-minimal inhibitory concentrations of antimicrobial agents on the cell surface of Klebsiella pneumoniae and phagocytic killing activity. J Chemother. 1995 Oct;7(5):406-13.

92 Ehrenworth L, Baer H. The pathogenicity of Klebsiella pneumoniae for mice: the relationship to the quantity and rate of production of type-specific capsular polysaccharide. J Bacteriol. 1956 Nov;72(5):713-7.

93 Domenico P, Salo RJ, Cross AS, Cunha BA. Polysaccharide capsule-mediated resistance to opsonophagocytosis in Klebsiella pneumoniae. Infect Immun. 1994 Oct;62(10): 4495-9.
94 Ernst CM, Braxton JR, Rodriguez-Osorio CA, Zagieboylo AP, Li L, Pironti A, et al. Adaptive evolution of virulence and persistence in carbapenem-resistant Klebsiella pneumoniae. Nat Med. 2020;26(5):705-11.

95 Kobayashi SD, Porter AR, Dorward DW, Brinkworth AJ, Chen L, Kreiswirth BN, et al. Phagocytosis and killing of carbapenem-resistant ST258 Klebsiella pneumoniae by human neutrophils. J Infect Dis. 2016 May; 213(10):1615-22.

96 Diago-Navarro E, Motley MP, Ruiz-Peréz G, Yu W, Austin J, Seco BMS, et al. Erratum for Diago-Navarro et al., "novel, broadly reactive anticapsular antibodies against carbapenem-resistant Klebsiella pneumoniae protect from infection”. mBio. 2018 04;9(3): e00091-18.

97 Kobayashi SD, Porter AR, Freedman B, Pandey R, Chen L, Kreiswirth BN, et al. Antibodymediated killing of carbapenem-resistant ST258 Klebsiella pneumoniae by human neutrophils.mBio.2018Mar-Apr;9(2)::e00297-18

98 Motley MP, Diago-Navarro E, Banerjee K, Inzerillo $\mathrm{S}$, Fries $\mathrm{BC}$. The role of IgG subclass in antibody-mediated protection against carbapenem-resistant Klebsiella pneumoniae. mBio. 2020 Sep 8;11(5):e02059-20.

99 Pan YJ, Lin TL, Hsu CR, Wang JT. Use of a Dictyostelium model for isolation of genetic loci associated with phagocytosis and virulence in Klebsiella pneumoniae. Infect Immun. 2011 Mar;79(3):997-1006.

100 Wu MF, Yang CY, Lin TL, Wang JT, Yang $\mathrm{FL}, \mathrm{Wu} \mathrm{SH}$, et al. Humoral immunity against capsule polysaccharide protects the host from magA+ Klebsiella pneumoniae-induced lethal disease by evading Toll-like receptor 4 signaling. Infect Immun. $2009 \mathrm{Feb}$; 77(2):615-21.

101 Ahn D, Peñaloza H, Wang Z, Wickersham M, Parker D, Patel P, et al. Acquired resistance to innate immune clearance promotes Klebsiella pneumoniae ST258 pulmonary infection. JCI Insight. 2016 Oct 20;1(17):e89704.

102 Evavold CL, Kagan JC. How inflammasomes inform adaptive immunity. J Mol Biol. 2018 Jan 19;430(2):217-37.

103 Bonilla FA, Oettgen HC. Adaptive immunity. J Allergy Clin Immunol. 2010 Feb; 125(2 Suppl 2):S33-40.

104 Lee WH, Choi HI, Hong SW, Kim KS, Gho YS, Jeon SG. Vaccination with Klebsiella pneumoniae-derived extracellular vesicles protects against bacteria-induced lethality via both humoral and cellular immunity. Exp Mol Med. 2015 Sep;47:e183.

105 Ye P, Garvey PB, Zhang P, Nelson S, Bagby G, Summer WR, et al. Interleukin-17 and lung host defense against Klebsiella pneumoniae infection. Am J Respir Cell Mol Biol. 2001 Sep;25(3):335-40.

106 Lin YC, Lu MC, Lin C, Chiang MK, Jan MS, Tang HL, et al. Activation of IFN- $\gamma /$ STAT/ IRF-1 in hepatic responses to Klebsiella pneumoniae infection. PLoS One. 2013, 8(11):e79961.
107 Weintraub A. Immunology of bacterial polysaccharide antigens. Carbohydr Res. 2003 Nov;338(23):2539-47.

108 Defrance T, Taillardet M, Genestier L. T cellindependent B cell memory. Curr Opin Immunol. 2011 Jun;23(3):330-6.

109 Lepper PM, Möricke A, Held TK, Schneider EM, Trautmann M. K-antigen-specific, but not $\mathrm{O}$-antigen-specific natural human serum antibodies promote phagocytosis of Klebsiella pneumoniae. FEMS Immunol Med Microbiol. 2003 Mar;35(2):93-8.

110 DeLeo FR, Kobayashi SD, Porter AR, Freedman B, Dorward DW, Chen L, et al. Survival of carbapenem-resistant Klebsiella pneumoniae sequence type 258 in human blood. Antimicrob Agents Chemother. 2017;61(4): e02533-16.

111 Young TM, Bray AS, Nagpal RK, Caudell DL, Yadav H, Zafar MA. Animal model to study Klebsiella pneumoniae gastrointestinal colonization and host-to-host transmission. Infect Immun. 2020 Oct 19;88(11): e00071-20.

112 Cheng HY, Chen YS, Wu CY, Chang HY, Lai YC, Peng HL. RmpA regulation of capsular polysaccharide biosynthesis in Klebsiella pneumoniae CG43. J Bacteriol. 2010 Jun; 192(12):3144-58.

113 Cubero M, Grau I, Tubau F, Pallarés R, Dominguez MA, Liñares J, et al. Hypervirulent Klebsiella pneumoniae clones causing bacteraemia in adults in a teaching hospital in Barcelona, Spain (2007-2013). Clin Microbiol Infect. 2016 Feb;22(2):154-60.

114 Walker KA, Miner TA, Palacios M, Trzilova D, Frederick DR, Broberg CA, et al. A Klebsiella pneumoniae regulatory mutant has reduced capsule expression but retains hypermucoviscosity. mBio. 2019;10(2):e00089-19.

115 Mike LA, Stark AJ, Forsyth VS, Vornhagen J, Smith SN, Bachman MA, et al. A systematic analysis of hypermucoviscosity and capsule reveals distinct and overlapping genes that impact Klebsiella pneumoniae fitness. PLoS Pathog. 2021 Mar;17(3):e1009376.

116 Nassif X, Sansonetti PJ. Correlation of the virulence of Klebsiella pneumoniae K1 and $\mathrm{K} 2$ with the presence of a plasmid encoding aerobactin. Infect Immun. 1986 Dec;54(3): 603-8.

117 Müller SI, Valdebenito M, Hantke K. Salmochelin, the long-overlooked catecholate siderophore of Salmonella. Biometals. 2009 Aug;22(4):691-5.

118 Hu D, Li Y, Ren P, Tian D, Chen W, Fu P, et al. Molecular epidemiology of hypervirulent carbapenemase-producing Klebsiella pneumoniae. Front Cell Infect Microbiol. 2021; 11:661218.

119 Holden VI, Bachman MA. Diverging roles of bacterial siderophores during infection. Metallomics. 2015 Jun;7(6):986-95.

120 Kramer J, Özkaya Ö, Kümmerli R. Bacterial siderophores in community and host interactions. Nat Rev Microbiol. 2020 Mar;18(3): $152-63$. 
121 Lin TL, Lee CZ, Hsieh PF, Tsai SF, Wang JT. Characterization of integrative and conjugative element ICEKp1-associated genomic heterogeneity in a Klebsiella pneumoniae strain isolated from a primary liver abscess. J Bacteriol. 2008 Jan;190(2):515-26.

122 Lam MMC, Wyres KL, Judd LM, Wick RR, Jenney A, Brisse $S$, et al. Tracking key virulence loci encoding aerobactin and salmochelin siderophore synthesis in Klebsiella pneumoniae. Genome Med. 2018;10(1):77.

123 Hsieh PF, Lin TL, Lee CZ, Tsai SF, Wang JT. Serum-induced iron-acquisition systems and TonB contribute to virulence in Klebsiella pneumoniae causing primary pyogenic liver abscess. J Infect Dis. 2008 Jun 15; 197(12):1717-27.

124 Russo TA, Olson R, Macdonald U, Metzger D, Maltese LM, Drake EJ, et al. Aerobactin mediates virulence and accounts for increased siderophore production under iron-limiting conditions by hypervirulent (hypermucoviscous) Klebsiella pneumoniae. Infect Immun. 2014 Jun;82(6): 2356-67.

125 Russo TA, Olson R, MacDonald U, Beanan J, Davidson BA. Aerobactin, but not yersiniabactin, salmochelin, or enterobactin, enables the growth/survival of hypervirulent (hypermucoviscous) Klebsiella pneumoniae ex vivo and in vivo. Infect Immun. 2015 Aug; 83(8):3325-33.

126 Duguid JP. Fimbriae and adhesive properties in Klebsiella strains. J Gen Microbiol. 1959 Aug;21:271-86.

127 Gerlach GF, Clegg S, Allen BL. Identification and characterization of the genes encoding the type 3 and type 1 fimbrial adhesins of Klebsiella pneumoniae. J Bacteriol. 1989 Mar;171(3):1262-70.

128 Struve C, Bojer M, Krogfelt KA. Identification of a conserved chromosomal region encoding Klebsiella pneumoniae type 1 and type 3 fimbriae and assessment of the role of fimbriae in pathogenicity. Infect Immun. 2009 Nov;77(11):5016-24.

129 Schroll C, Barken KB, Krogfelt KA, Struve C. Role of type 1 and type 3 fimbriae in Klebsiella pneumoniae biofilm formation. BMC Microbiol. 2010 Jun;10:179.

130 Ofek I, Mirelman D, Sharon N. Adherence of Escherichia coli to human mucosal cells mediated by mannose receptors. Nature. 1977 Feb 17;265(5595):623-5.

131 Clegg S, Gerlach GF. Enterobacterial fimbriae. J Bacteriol. 1987 Mar;169(3):934-8.

132 Struve C, Bojer M, Krogfelt KA. Characterization of Klebsiella pneumoniae type $1 \mathrm{fim}$ briae by detection of phase variation during colonization and infection and impact on virulence. Infect Immun. 2008 Sep;76(9): 4055-65.

133 Di Martino P, Cafferini N, Joly B, DarfeuilleMichaud A. Klebsiella pneumoniae type 3 pili facilitate adherence and biofilm formation on abiotic surfaces. Res Microbiol. 2003 2003 Jan-Feb;154(1):9-16.
134 Jagnow J, Clegg S. Klebsiella pneumoniae MrkD-mediated biofilm formation on extracellular matrix- and collagen-coated surfaces. Microbiology (Reading). 2003 Sep; 149(Pt 9):2397-405.

135 Di Martino P, Bertin Y, Girardeau JP, Livrelli V, Joly B, Darfeuille-Michaud A. Molecular characterization and adhesive properties of CF29K, an adhesin of Klebsiella pneumoniae strains involved in nosocomial infections. Infect Immun. 1995 Nov;63(11): 4336-44.

136 Di Martino P, Livrelli V, Sirot D, Joly B, Darfeuille-Michaud A. A new fimbrial antigen harbored by CAZ-5/SHV-4-producing Klebsiella pneumoniae strains involved in nosocomial infections. Infect Immun. 1996 Jun;64(6):2266-73.

137 Paczosa MK, Silver RJ, McCabe AL, Tai AK, McLeish CH, Lazinski DW, et al. Transposon mutagenesis screen of Klebsiella pneumoniae identifies multiple genes important for resisting antimicrobial activities of neutrophils in mice. Infect Immun. 2020;88(4).

138 Valentino MD, Foulston L, Sadaka A, Kos VN, Villet RA, Santa Maria J Jr, et al. Genes contributing to Staphylococcus aureus fitness in abscess- and infection-related ecologies. mBio. 2014 Sep 2;5(5):e01729-14.

139 Sanchez-Larrayoz AF, Elhosseiny NM, Chevrette MG, Fu Y, Giunta P, Spallanzani RG, et al. Complexity of complement resistance factors expressed by Acinetobacter baumannii needed for survival in human serum. J Immunol. 2017 Oct 15;199(8):2803-14.

140 Grosser MR, Paluscio E, Thurlow LR, Dillon MM, Cooper VS, Kawula TH, et al. Genetic requirements for Staphylococcus aureus nitric oxide resistance and virulence. PLoS Pathog. 2018 Mar;14(3):e1006907.

141 Poulsen BE, Yang R, Clatworthy AE, White T, Osmulski SJ, Li L, et al. Defining the core essential genome of Pseudomonas aeruginosa. Proc Natl Acad Sci U S A. 2019 May 14;116(20):10072-80.

142 Rowe HM, Karlsson E, Echlin H, Chang TC, Wang L, van Opijnen T, et al. Bacterial factors required for transmission of Streptococcus pneumoniae in mammalian hosts. Cell Host Microbe. 2019 Jun 12;25(6):884-91.e6.

143 Eichelberger KR, Sepúlveda VE, Ford J, Selitsky SR, Mieczkowski PA, Parker JS, et al. Tn-seq analysis identifies genes important for Yersinia pestis adherence during primary pneumonic plague. mSphere. 2020 Aug 5; 5(4):e00715-20.

144 Zhu L, Olsen RJ, Beres SB, Saavedra MO, Kubiak SL, Cantu CC, et al. Streptococcus pyogenes genes that promote pharyngitis in primates. JCI Insight. 2020 Jun 4;5(11): e137686.

145 Zhu L, Yerramilli P, Pruitt L, Ojeda Saavedra M, Cantu CC, Olsen RJ, et al. Genome-wide assessment of Streptococcus agalactiae genes required for survival in human whole blood and plasma. Infect Immun. 2020 Sep 18;88(10):e00357-20.
146 Mobegi FM, van Hijum SA, Burghout P, Bootsma HJ, de Vries SP, van der Gaast-de Jongh CE, et al. From microbial gene essentiality to novel antimicrobial drug targets. BMC Genomics. 2014 Nov 5; 15:958.

147 Coe KA, Lee W, Stone MC, Komazin-Meredith G, Meredith TC, Grad YH, et al. Multistrain Tn-Seq reveals common daptomycin resistance determinants in Staphylococcus aureus. PLoS Pathog. 2019 Nov;15(11): e1007862.

148 Tzouvelekis LS, Miriagou V, Kotsakis SD Spyridopoulou K, Athanasiou E, Karagouni E, et al. KPC-producing, multidrug-resistant Klebsiella pneumoniae sequence type 258 as a typical opportunistic pathogen. Antimicrob Agents Chemother. 2013 Oct;57(10): 5144-6.

149 Sequeira RP, McDonald JAK, Marchesi JR, Clarke TB. Commensal Bacteroidetes protect against Klebsiella pneumoniae colonization and transmission through IL-36 signalling. Nat Microbiol. 2020 02;5(2):304-13.

150 Good RC, May BD. Respiratory pathogens in monkeys. Infect Immun. 1971 Jan;3(1) 87-93.

151 Malachowa N, Kobayashi SD, Porter AR, Freedman B, Hanley PW, Lovaglio J, et al. Vaccine protection against multidrug-resistant Klebsiella pneumoniae in a nonhuman primate model of severe lower respiratory tract infection. mBio. 2019;10(6): $022994-$ 19.

152 Dumigan A, Fitzgerald M, Santos JSG, Hamid U, O'Kane CM, McAuley DF, et al. A porcine ex vivo lung perfusion model to investigate bacterial pathogenesis. mBio. 2019 12;10(6):e02802-19.

153 Iwanaga N, Sandquist I, Wanek A, McCombs J, Song K, Kolls JK. Host immunology and rational immunotherapy for carbapenem-resistant Klebsiella pneumoniae infection. JCI Insight. 2020 Apr;5(8):e135591.

154 Jones-Nelson O, Tovchigrechko A, Glover MS, Fernandes F, Rangaswamy U, Liu H, et al. Antibacterial monoclonal antibodies do not disrupt the intestinal microbiome or its function. Antimicrob Agents Chemother. 2020;64(5):e02347-19.

155 Diago-Navarro E, Calatayud-Baselga I, Sun D, Khairallah C, Mann I, Ulacia-Hernando A, et al. Antibody-based immunotherapy to treat and prevent infection with hypervirulent Klebsiella pneumoniae. Clin Vaccine Immunol. 2017 Jan;24(1):e00456-16.

156 Cohen TS, Pelletier M, Cheng L, Pennini ME, Bonnell J, Cvitkovic R, et al. Anti-LPS antibodies protect against Klebsiella pneumoniae by empowering neutrophil-mediated clearance without neutralizing TLR4. JCI Insight. 2017 May 4;2(9):e92774.

157 Pennini ME, De Marco A, Pelletier M, Bonnell J, Cvitkovic R, Beltramello M, et al. Immune stealth-driven $\mathrm{O} 2$ serotype prevalence and potential for therapeutic antibodies against multidrug resistant Klebsiella pneumoniae. Nat Commun. 2017 Dec 8;8(1):1991. 
158 Giesker K, Hensel M. Bacterial vaccines. Ref Mod Bio Sci. 2014;119:1-7.

159 Lorenzo-Gómez MF, Padilla-Fernández B, García-Cenador MB, Virseda-Rodríguez ÁJ, Martín-García I, Sánchez-Escudero A, et al. Comparison of sublingual therapeutic vaccine with antibiotics for the prophylaxis of recurrent urinary tract infections. Front Cell Infect Microbiol. 2015;5:50.

160 Nickel JC, Saz-Leal P, Doiron RC. Could sublingual vaccination be a viable option for the prevention of recurrent urinary tract infection in Canada? A systematic review of the current literature and plans for the future. Can Urol Assoc J. 2020 Aug;14(8):2817.

161 Yang B, Foley S. First experience in the UK of treating women with recurrent urinary tract infections with the bacterial vaccine Uromune ${ }^{\oplus}$. BJU Int. 2018 Feb;121(2):28992.

162 Chen K, McAleer JP, Lin Y, Paterson DL, Zheng M, Alcorn JF, et al. Th17 cells mediate clade-specific, serotype-independent mucosal immunity. Immunity. 2011 Dec;35(6): 997-1009.

163 Bjune G, Høiby EA, Grønnesby JK, Arnesen $\mathrm{O}$, Fredriksen JH, Halstensen A, et al. Effect of outer membrane vesicle vaccine against group B meningococcal disease in Norway. Lancet. 1991 Nov 2;338(8775):1093-6.

164 Lee JC, Lee EJ, Lee JH, Jun SH, Choi CW, Kim SI, et al. Klebsiella pneumoniae secretes outer membrane vesicles that induce the innate immune response. FEMS Microbiol Lett. 2012 Jun;331(1):17-24.

165 Wu G, Ji H, Guo X, Li Y, Ren T, Dong H, et al. Nanoparticle reinforced bacterial outermembrane vesicles effectively prevent fatal infection of carbapenem-resistant Klebsiella pneumoniae. Nanomedicine. 2020;24: 102148.

166 Hayward S, Thompson LA, McEachern A. Is 13-valent pneumococcal conjugate vaccine (PCV13) combined with 23-valent pneumococcal polysaccharide vaccine (PPSV23) superior to PPSV23 alone for reducing incidence or severity of pneumonia in older adults? A Clin-IQ. J Patient Cent Res Rev. 2016;3(2):111-5.

167 Presa J, Findlow J, Vojicic J, Williams S, Serra L. Epidemiologic trends, global shifts in meningococcal vaccination guidelines, and data supporting the use of MenACWY-TT vaccine: a review. Infect Dis Ther. 2019 Sep; 8(3):307-33.
168 Cryz SJ, Fürer E, Germanier R. Purification and vaccine potential of Klebsiella capsular polysaccharides. Infect Immun. 1985 Oct; 50(1):225-30.

169 Feldman MF, Mayer Bridwell AE, Scott NE, Vinogradov E, McKee SR, Chavez SM, et al. A promising bioconjugate vaccine against hypervirulent Klebsiella pneumoniae. Proc Natl Acad Sci U S A. 2019 Sep 10;116(37): 18655-63.

170 Seeberger PH, Pereira CL, Khan N, Xiao G, Diago-Navarro E, Reppe K, et al. A semisynthetic glycoconjugate vaccine candidate for carbapenem-resistant Klebsiella pneumoniae. Angew Chem Int Ed Engl. 2017; 56(45):13973-8.

171 Hegerle N, Choi M, Sinclair J, Amin MN, Ollivault-Shiflett M, Curtis B, et al. Development of a broad spectrum glycoconjugate vaccine to prevent wound and disseminated infections with Klebsiella pneumoniae and Pseudomonas aeruginosa. PLoS One. 2018; 13(9):e0203143.

172 Wang Q, Chang CS, Pennini M, Pelletier M, Rajan S, Zha J, et al. Target-agnostic identification of functional monoclonal antibodies against Klebsiella pneumoniae multimeric MrkA fimbrial subunit. J Infect Dis. 2016;213(11):1800-8.

173 Gorden PJ, Kleinhenz MD, Ydstie JA, Brick TA, Slinden LM, Peterson MP, et al. Efficacy of vaccination with a Klebsiella pneumoniae siderophore receptor protein vaccine for reduction of Klebsiella mastitis in lactating cattle. J Dairy Sci. 2018 Nov; 101(11):10398-408.

174 Babu L, Uppalapati SR, Sripathy MH, Reddy PN. Evaluation of Recombinant multi-epitope outer membrane protein-based Klebsiella pneumoniae subunit vaccine in mouse model. Front Microbiol. 2017;8:1805.

175 Suresh MV, Thomas B, Machado-Aranda D, Dolgachev VA, Kumar Ramakrishnan S, Talarico N, et al. Double-stranded RNA interacts with toll-like receptor 3 in driving the acute inflammatory response following lung contusion. Crit Care Med. 2016 Nov;44(11): e1054-e66.

176 Suresh MV, Dolgachev VA, Zhang B, Balijepalli S, Swamy S, Mooliyil J, et al. TLR3 absence confers increased survival with improved macrophage activity against pneumonia. JCI Insight. 2019;4(23):e131195.

177 Wang Q, Chen Y, Pelletier M, Cvitkovic R, Bonnell J, Chang CY, et al. Enhancement of antibody functions through $\mathrm{Fc}$ multiplications. MAbs. 2017;9(3):393-403.
178 Hesse S, Adhya S. Phage therapy in the twenty-first century: facing the decline of the antibiotic era; is it finally time for the age of the phage? Annu Rev Microbiol. 2019;73:15574.

179 Onsea J, Soentjens P, Djebara S, Merabishvili M, Depypere M, Spriet I, et al. Bacteriophage application for difficult-to-treat musculoskeletal infections: development of a standardized multidisciplinary treatment protocol. Viruses. 2019;11(10):891.

180 Gu Liu C, Green SI, Min L, Clark JR, Salazar $\mathrm{KC}$, Terwilliger AL, et al. Phage-antibiotic synergy is driven by a unique combination of antibacterial mechanism of action and stoichiometry. mBio. 2020 Aug; 11(4): e01462-20.

181 Taati Moghadam M, Khoshbayan A, Chegini Z, Farahani I, Shariati A. Bacteriophages, a new therapeutic solution for inhibiting multidrug-resistant bacteria causing wound infection: lesson from animal models and clinical trials. Drug Des Devel Ther. 2020;14: 1867-83.

182 Roach DR, Debarbieux L. Phage therapy: awakening a sleeping giant. Emerg Top Life Sci. 2017;1(1):93-103.

183 El Haddad L, Harb CP, Gebara MA, Stibich MA, Chemaly RF. A systematic and critical review of bacteriophage therapy against multidrug-resistant ESKAPE organisms in humans. Clin Infect Dis. 2019;69(1):167-78.

184 Cano EJ, Caflisch KM, Bollyky PL, Van Belleghem JD, Patel R, Fackler J, et al. Phage therapy for limb-threatening prosthetic knee Klebsiella pneumoniae infection: case report and in vitro characterization of antibiofilm activity. Clin Infect Dis. 2021 Jul 1; 73(1):e144-51.

185 Hyman P, Abedon ST. Bacteriophage host range and bacterial resistance. Adv Appl Microbiol. 2010;70:217-48.

186 Hesse S, Rajaure M, Wall E, Johnson J, Bliskovsky V, Gottesman S, et al. Phage resistance in multidrug-resistant Klebsiella pneumoniae ST258 evolves via diverse mutations that culminate in impaired adsorption. mBio. 2020;11(1):e02530-19.

187 Hesse S, Malachowa N, Porter AR, Freedman B, Kobayashi SD, Gardner DJ, et al. Bacteriophage treatment rescues mice infected with multidrug-resistant Klebsiella pneumoniae ST258. mBio. 2021 Feb 23; 12(1):e00034-21. 